\title{
The importance of provocation tests with COX2 inhibitors on patients with a history of cross-hypersensitivity to non-steroidal anti-inflammatory (NSAIDs)
}

\author{
Tania Tavares Gonçalves \\ From 3rd WAO International Scientific Conference (WISC) 2014 \\ Rio de Janeiro, Brazil. 6-9 December 2014
}

\section{Background}

To verify the importance of provocation tests with COX2 selective inhibitors before release as an alternative medication, on patients with a record of crosshypersensitivity to non-steroidal anti-inflammatory (NSAIDs)

\section{Methods}

Retrospective analysis of patient records submitted to provocation tests with COX2 selected inhibitors, in Policlínica Geral do Rio de Janeiro, in the period between October 2010 and July 2014. The provocation tests were simple blind controlled placebo.

\section{Results}

One hundred and twenty provocation tests were done with COX2 selected inhibitors, out of which, 116 with etoricoxib $(96,6 \%)$ and 4 with celecoxib $(3,3 \%)$. One hundred and two patients were female, with predominance in ages between 40 and 64 years old $(41,8 \%$ of the women). Men represented only $15.9 \%$ of patients, with predominance in ages between 12 and 30 years old $(40,10 \%$ of the men). Five positive tests occurred $(4,1 \%)$, all of them tested with etoricoxib. In positive cases, 4 patients were female and 1 male, with predominance in ages between 17 and 29 years old, and 1 patient of 60 years old.

\section{Conclusions}

The liberation of alternative medication for patients with cross-hypersensitivity to NSAIDs should be permitted

Policlinica Geral Do Rio De Janeiro, Brazil only after the realization of provocation tests with COX2 selective inhibitors, given that $4 \%$ of the tests are positive.

Published: 8 April 2015

doi:10.1186/1939-4551-8-S1-A213

Cite this article as: Gonçalves: The importance of provocation tests with COX2 inhibitors on patients with a history of cross-hypersensitivity to non-steroidal anti-inflammatory (NSAIDs). World Allergy Organization Journal 2015 8(Suppl 1):A213.
Submit your next manuscript to BioMed Central and take full advantage of:

- Convenient online submission

- Thorough peer review

- No space constraints or color figure charges

- Immediate publication on acceptance

- Inclusion in PubMed, CAS, Scopus and Google Scholar

- Research which is freely available for redistribution

Submit your manuscript at www.biomedcentral.com/submit
() Biomed Central 